\title{
The effect of CAG repeat polymorphism in the glucocorticoid receptor on stress responses of mice exposed to water-immersion restraint stress
}

\author{
MASAFUMI TOMITA ${ }^{1}$, HIRONOBU KATSUYAMA ${ }^{2}$, TOSHIKO OKUYAMA ${ }^{1}$, \\ YOKO WATANABE ${ }^{3}$, KAZUO HIDAKA $^{3}$, TAKEMI OTSUKI ${ }^{4}$ and MASAYUKI NATA ${ }^{5}$ \\ Departments of ${ }^{1}$ Medical Toxicology; ${ }^{2}$ Public Health; ${ }^{3}$ Natural Sciences, Division of Chemistry; \\ ${ }^{4}$ Hygiene, Kawasaki Medical School, Kurashiki 701-0192; ${ }^{5}$ Department of Forensic Medicine and Science, \\ Mie University Graduate School of Medicine, Tsu 514-8507, Japan
}

Received October 26, 2009; Accepted November 30, 2009

DOI: 10.3892/ijmm_00000360

\begin{abstract}
Exposure to stress activates the hypothalamuspituitary-adrenal (HPA) axis, which is followed by an increase in production of its end product, corticosterone, considered to be the most important glucocorticoid (GC) in rodents. Glucocorticoid receptor (GR) signaling has been suggested as a potential mechanism responsible for the pathogenesis of many clinical disorders. Here, we investigated the involvement of the GR polymorphism in stress response. ICR mice were screened by genomic PCR, bred, and divided into 3 groups according to the GR polymorphism, GR ${ }^{\mathrm{wt} / \mathrm{wt}}, \mathrm{GR}^{\mathrm{wt} / \mathrm{Qn}}$, and $\mathrm{GR}^{\mathrm{Qn} / \mathrm{Qn}}$. Mice were exposed to water-immersion restraint stress (WRS), and then examined for gastric mucosal lesions, serum corticosterone, serum cytokines and serum Hsp70 levels. Male mice with $\mathrm{GR}^{\mathrm{Q} / \mathrm{Qn}}$ exhibited a significantly greater gastric lesion index than those with $\mathrm{GR}^{\mathrm{wt} / \mathrm{wt}}$ at $6 \mathrm{~h}$ of WRS. Stress-induced corticosterone output achieved peak levels at $3 \mathrm{~h}$, after which it was downregulated. The serum level in the control group was $\mathrm{GR}^{\mathrm{wt} / \mathrm{wt}}>\mathrm{GR}^{\mathrm{wt} / \mathrm{Qn}}>\mathrm{GR}^{\mathrm{Qn} / \mathrm{Qn}}$, whereas the order at $6 \mathrm{~h}$ of WRS was reversed, $\mathrm{GR}^{\mathrm{Qn} / \mathrm{Qn}}>\mathrm{GR}^{\mathrm{wt} / \mathrm{Qn}}>\mathrm{GR}^{\mathrm{wt} / \mathrm{wt}}$, suggesting that the $\mathrm{GR}^{\mathrm{wt}}$ allele responded rapidly to stress. The IL- 6 levels of each polymorphic line increased at $3 \mathrm{~h}$ and particularly at $6 \mathrm{~h}$. On the contrary, the IL-10 levels in GR ${ }^{\mathrm{wt} / \mathrm{wt}}$ and GR ${ }^{\mathrm{wt} / \mathrm{Qn}}$ increased following exposure to WRS, whereas that in $\mathrm{GR}^{\mathrm{Qn} / \mathrm{Qn}}$ showed no change. The Hsp70 levels in mice with $\mathrm{GR}^{\mathrm{Qn}}$ allele particularly increased at $6 \mathrm{~h}$ of WRS, and the concentration in $\mathrm{GR}^{\mathrm{Q}}{ }^{\mathrm{Q} / \mathrm{Qn}^{\mathrm{n}}}$ significantly increased as compared to that in $\mathrm{GR}^{\mathrm{wt} / \mathrm{wt}}$. These results suggest that the GR gene polymorphism has a significant impact on the stress-induced output, including the gastric lesion index, corticosterone, cytokines, and Hsp70 levels in serum. The present study
\end{abstract}

Correspondence to: Dr Masafumi Tomita, Department of Medical Toxicology, Kawasaki Medical School, 577 Matsushima, Kurashiki 701-0192, Japan

E-mail: toxicology@med.kawasaki-m.ac.jp

Key words: glucocorticoid receptor, polymorphism, waterimmersion restraint stress, gastric injury, cytokine, HSP70, mouse provides insights into the role of GR in individual responses to stress.

\section{Introduction}

Stress-induced abnormality is a highly complex phenomenon that occurs due to an interaction between genetic and environmental factors. A major stress-responsive/regulatory gene that has been extensively studied is the glucocorticoid receptor (GR) gene (1-3). It mediates many of the effects of glucocorticoid on target tissues by directly binding to elements in the DNA or by interacting with other transcription factors resulting in a modulation of the gene transcription. A common endocrine feature of stress response is the activation of the hypothalamus-pituitary-adrenal (HPA) axis, resulting in an increase in its end product, corticosterone, which is the most important glucocorticoid in rodents. The hormone binds to GR to impact many systems, such as the HPA axis itself, the immune system, metabolism, and behavior. Thus, GR is a key component in the HPA-related regulation of stress responses.

In humans, polymorphisms in the GR gene are thought to be of clinical relevance $(4,5)$. GR polymorphisms may be related to both treatment outcome and HPA-axis activity in outpatients with major depression (6). Wüst et al (7) provided further evidence of the effect of GR gene polymorphisms on HPA axis regulation to psychosocial stress, including individual vulnerability for HPA-related clinical states. These findings indicate that stress effects vary significantly among individuals with genetic differences associated with polymorphic GR genes.

Experimental murine genetic models of complex human diseases show great potential for understanding human disease pathogenesis. The CAG repeat regions in the mouse GR gene have been previously described (8). Xu et al (9) have reported that the polymorphic form of mouse GR plays a critical role in complex mechanisms leading to corticosterone responses and anxiety-type behavior to restraint stress. Other studies have demonstrated that the polymorphism in CAG repeat affects GR activity (10).

The water-immersion restraint stress (WRS) model is often used as a 'stressor' for the induction of stress response 
syndromes in animals $(11,12)$. In addition, WRS affects the inflammatory cascade, but its impact on immunity remains to be determined. Extensive evidence indicates that the blood IL-6 level is increased after application of not only inflammatory stimuli but also stressors (13-15). Chida et al (16) have reported that the endogenous norepinephrine is responsible for stressinduced IL-6 production. On the other hand, heat shock proteins (Hsps), also known as stress proteins, are increased in a number of pathological conditions. Hsp70 is one of the important Hsps involved in gastric mucosal protection. Overexpression of Hsp70 has been found in the gastric mucosa of rats with gastric ulcers $(17,18)$.

In the present study, we performed genetic screening for the GR polymorphism using the commonly used ICR mouse strain and divided them into GR polymorphic lines. Thereafter, we examined the involvement of GR polymorphisms in the response of mice to WRS.

\section{Materials and methods}

Animals and genetic selection. All experiments were approved by the Animal Research Committee of Kawasaki Medical School, Japan, and conducted according to the 'Guide for the Care and Use of Laboratory Animals' established by the Kawasaki Medical School, Japan. Adult male and female ICR mice (7-8 weeks old) were obtained from CLEA Japan. The initial selection for the GR genotype was done by PCR. Genomic DNA was prepared from tail snips (ca. $0.5 \mathrm{~cm}$ ) using the Gentra Puregene Mouse Tail Kit (Qiagen). The following primer pairs were used as described elsewhere (9), forward, 5'-CTGCTTCTCAGGCAGATTCC-3' and reverse, 5'-TCCA GAAGCCGAAAGTCTGT-3'. Following PCR and gel electrophoresis, mice were divided into 3 GR polymorphic lines: (i) GR ${ }^{\mathrm{wt} / \mathrm{wt}}$, wild-type with 8 glutamine repeats; (ii) $\mathrm{GR}^{\mathrm{Qn} / \mathrm{Qn}}$, an expanded track of 16 glutamine repeats; and (iii) $\mathrm{GR}^{\mathrm{w} t / \mathrm{Qn}}$, the heterozygous form. Mice were then allowed to mate with other mice from the same line to obtain appropriate numbers of each GR genotype. Four to five mice were housed per polycarbonate cage and maintained in a controlled environment at $23 \pm 1^{\circ} \mathrm{C}$ with a relative humidity of $45-50 \%$ and a 12-h light/dark cycle. The mice had free access to commercial rodent MF pellets (Oriental Yeast) and tap water.

Induction of gastric lesions and sample collection. In this experiment, 7-9 week-old mice were used. Animals were fasted overnight in cages with wide mesh wire bottoms to prevent coprophagy and had free access to tap water. The animals with each GR genotype were randomly assigned into the following groups: (i) control, (ii) $1 \mathrm{~h}$ WRS (WRS/1 h), (iii) $3 \mathrm{~h} \mathrm{WRS}$ (WRS/3 h), and (iv) $6 \mathrm{~h} \mathrm{WRS} \mathrm{(WRS/6} \mathrm{h).} \mathrm{Mice} \mathrm{in} \mathrm{the} \mathrm{control}$ group were not exposed to WRS. The WRS method has been described in detail previously (11). Briefly, mice were restrained in a 50-ml conical centrifuge tube filled with multiple punctures and immersed vertically to the level of the xiphoid process into a $24 \pm 1^{\circ} \mathrm{C}$ water bath. After exposure to WRS, mice were anesthetized with sodium pentobarbital (50 $\mathrm{mg} / \mathrm{kg}$, i.p.), then intracardiac blood was collected, centrifuged, and the serum obtained was stored at $-80^{\circ} \mathrm{C}$ until analysis. Animals were sacrificed between 15:00 and 16:30. The stomachs were filled with $4 \%$ formalin for $15 \mathrm{~min}$, and then they were removed quickly. The stomachs were dissected along the greater curvature and examined for mucosal lesions. Lesion size was determined by measuring the greater diameter of the lesion and was expressed as the lesion index (19).

Assay of corticosterone, cytokines, and Hsp70 in serum. The corticosterone levels in the serum were determined by a Correlate-EIA Immunoassay kit (Assay Design), according to the protocol for small volume samples provided by the company. Cytokine analyses were performed by using the murine inflammatory cytokine bead array (BD Biosciences). Flow cytometry was conducted by using the FACSCalibur (BD Biosciences), and data were analyzed by using the CBA software. The cytokines analyzed by this method were IL-6, IL-10, IL-12p70, TNF- $\alpha$, IFN- $\gamma$, and MCP-1. The Hsp70 in the serum was determined by using a commercially available EIA kit (Assay Design), with slight modifications to the manufacturer's instructions. Briefly, we incubated serum samples in wells coated with a specific antibody overnight at $4^{\circ} \mathrm{C}$. The serum samples were diluted 80 -fold (for corticosterone) or 2-fold (for cytokines and Hsp70) with assay buffers in each kit and were then subjected to the assay.

Statistical analysis. The data are presented as means \pm SD. Statistical analyses were performed with one-way analysis of variance (ANOVA), followed by the Tukey-Kramer test. p-values of $<0.05$ were considered statistically significant.

\section{Results}

GR polymorphic lines in the ICR mouse strain were screened by determining the difference in size of the PCR products for the GR coding region. The size difference between $\mathrm{GR}^{\mathrm{wt}}$ and $\mathrm{GR}^{\mathrm{Qn}}$ alleles depended on $8 \mathrm{CAG}$ repeats (8 glutamines) as described by $\mathrm{Xu}$ et al (9). The allele frequency in the ICR mouse strain commercially obtained was $77.9 \%$ for the GR ${ }^{\mathrm{wt}}$ allele and $22.1 \%$ for the $\mathrm{GR}^{\mathrm{Qn}}$ one $(\mathrm{n}=112)$. No gender difference was observed.

WRS-induced gastric lesions. Following exposure to WRS, mice developed severe gastric lesions in a time-dependent manner. Medium- and/or large-size blood clots were observed on the gastric mucosal membranes (Fig. 1). A few small lesions, including petechial bleeding, were also detected in the control group subjected to overnight fasting. Further quantitative estimation of the gastric lesions indicates that the male mice with $\mathrm{GR}^{\mathrm{Qn} / \mathrm{Qn}}$ exhibited a much greater injurious response than those with $\mathrm{GR}^{\mathrm{wt} / \mathrm{wt}}$ at $6 \mathrm{~h}$ exposure to WRS (37.0 \pm 5.1 vs. $22.1 \pm 4.8$, p $<0.05$; Fig. 2). Although female mice also showed the time-dependent development of severe gastric lesions, the severity of the lesions was weaker than those observed in male mice, and no significant difference was observed in the gastric lesion index among the GR polymorphic lines (data not shown).

WRS-induced corticosterone levels in serum. As stress response is associated with a rise in corticosterone levels in the blood, we compared the corticosterone concentration among the GR polymorphic lines following exposure to WRS (Fig. 3). There was no difference in the serum corticosterone levels among the 

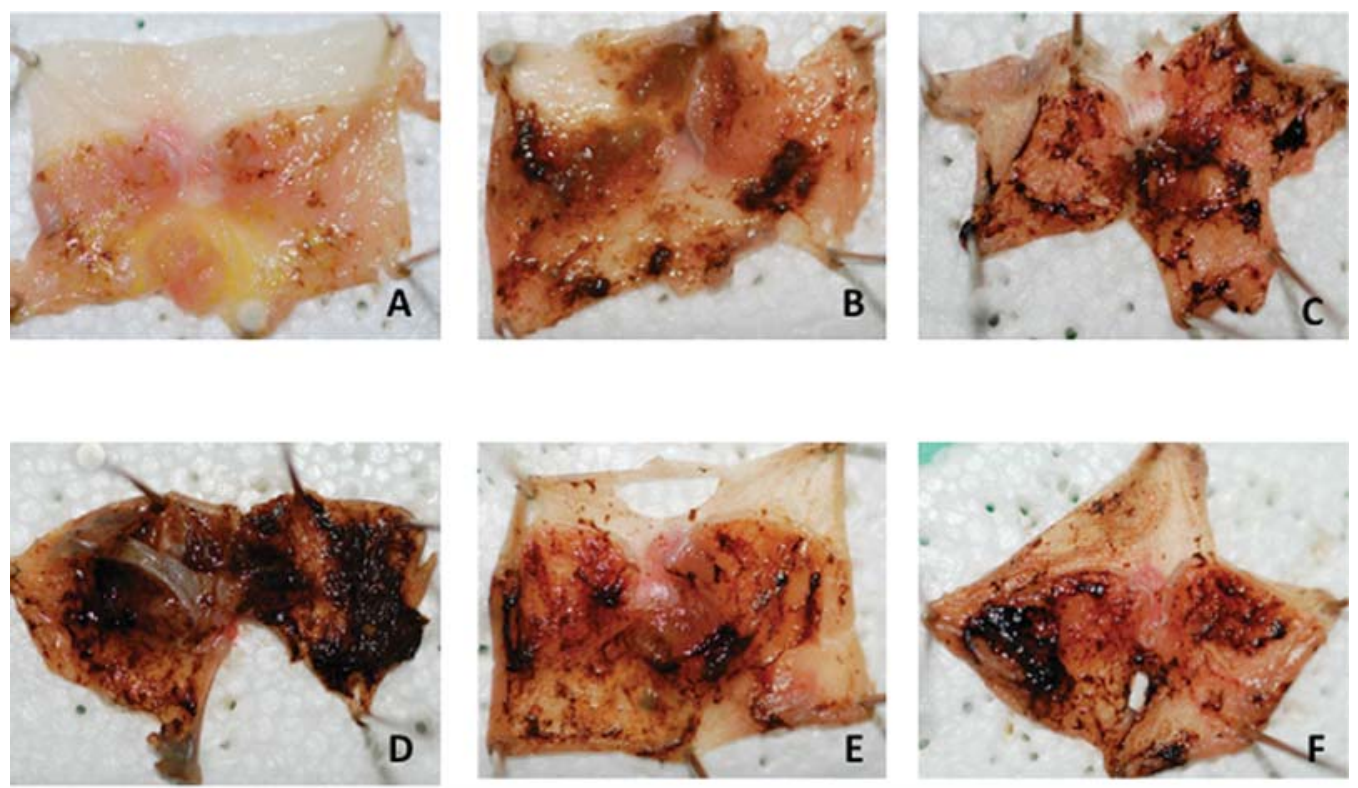

Figure 1. An overview of the WRS-induced bleeding on the gastric mucosal membranes in male mice. Only the changes in housing conditions and overnight fasting resulted in minor petechial bleeding (A). A-D, GR ${ }^{\mathrm{Qn} / \mathrm{Qn}} ; \mathrm{E}, \mathrm{F}, \mathrm{GR}^{\mathrm{wt} / \mathrm{wt}}$; A, control (overnight fasting); B, WRS/1 h; C,E, WRS/3 h; D,F, WRS/6 h.

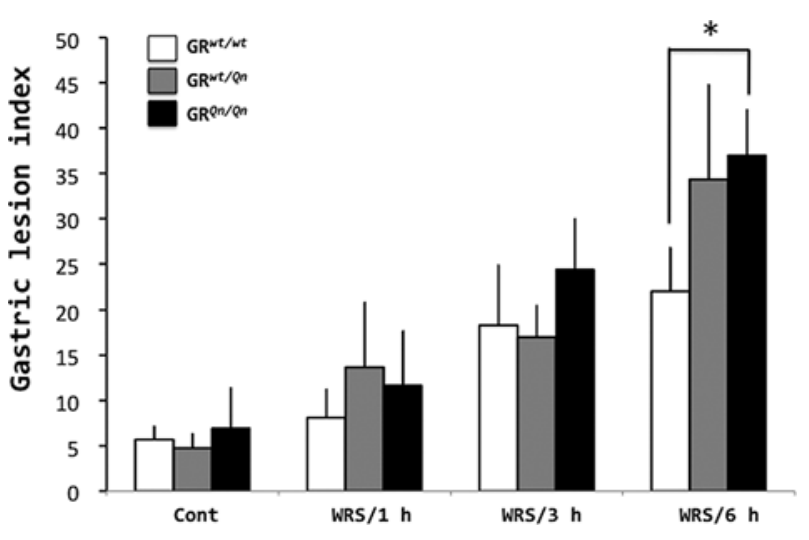

Figure 2. Time course of gastric lesion index in the GR polymorphic lines of ICR mice after exposure to WRS. ${ }^{*} \mathrm{p}<0.05$.

polymorphic lines in normal groups. Only overnight fasting, including changes in housing conditions, resulted in an increase in the levels. In particular, a significant increase was observed in mice with the $\mathrm{GR}^{\mathrm{wt}}$ allele as compared to each normal value $(\mathrm{p}<0.05)$, and the rank order of these levels in the control group was $\mathrm{GR}^{\mathrm{wt} / \mathrm{wt}}>\mathrm{GR}^{\mathrm{wt} / \mathrm{Qnt}}>\mathrm{GR}^{\mathrm{Qn} / \mathrm{Qn}}$. The maximum level of corticosterone response was achieved at $3 \mathrm{~h}$ of WRS $(\mathrm{p}<0.01$ from normal value), after which it was downregulated. The level in $\mathrm{GR}^{\mathrm{wt} / \mathrm{wt}}$ mice was significantly decreased at $6 \mathrm{~h}(\mathrm{p}<0.05$, vs. at $3 \mathrm{~h}$ ), and the order of the levels at $6 \mathrm{~h}$ of WRS was $\mathrm{GR}^{\mathrm{Qn} / \mathrm{Qn}^{\mathrm{n}}}>\mathrm{GR}^{\mathrm{wt} / \mathrm{Qn}}>\mathrm{GR}^{\mathrm{wt} / \mathrm{wt}}$, which was reverse of the order determined at $3 \mathrm{~h}$ of WRS. The corticosterone levels in $\mathrm{GR}^{\mathrm{Qn} / \mathrm{Qn}}$ mice were significantly increased as compared to that in $\mathrm{GR}^{\mathrm{wt} / \mathrm{wt}}$ mice in response to $6 \mathrm{~h}$ of WRS $(\mathrm{p}<0.05)$. These results suggest that the GR allele is involved in altered corticosterone response to WRS and that the $\mathrm{GR}^{\mathrm{wt}}$ allele allows for a more rapid response to stress as compared to the $\mathrm{GR}^{\mathrm{Qn}}$ allele.

WRS-induced cytokine levels in serum. Recent studies have provided evidence of the involvement of glucocorticoid in the

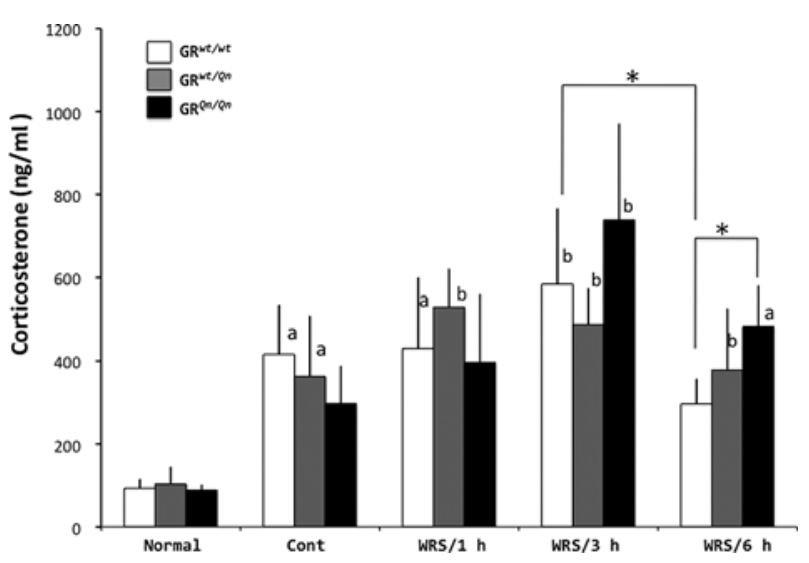

Figure 3. Time course of serum corticosterone concentration in the GR polymorphic lines of ICR mice after exposure to WRS. ${ }^{a} \mathrm{p}<0.05$ vs. normal; ${ }^{\mathrm{b}} \mathrm{p}<0.01$ vs. normal; ${ }^{*} \mathrm{p}<0.05$.

maintenance of homeostasis during stress. In this study, we examined the involvement of the GR allele in WRS-induced changes in serum cytokine levels. The IL-6 level in the serum of each polymorphic line was significantly increased at 3 and $6 \mathrm{~h}(\mathrm{p}<0.01)$ following exposure to WRS (Fig. 4A). On the other hand, the effect of WRS on the IL-10 serum concentration differed among the GR polymorphic lines. IL-10 levels in mice with $G^{\text {wt/wt }}$ and GR ${ }^{\mathrm{wt} / \mathrm{Qn}}$ showed a trend towards an increase following exposure to WRS, whereas those with $\mathrm{GR}^{\mathrm{Qn} / \mathrm{Qn}}$ showed no change (Fig. 4B). Thus, the ratio of IL-6/IL-10 was significantly high, in the order of $\mathrm{GR}^{\mathrm{Qn} / \mathrm{Qn}^{n}}>\mathrm{GR}_{\mathrm{wt} / \mathrm{Qn}}>\mathrm{GR}^{\mathrm{wt} / \mathrm{wt}}$ at 3 and 6 h of WRS (Fig. 5). The IL-6/IL-10 ratio in GR ${ }^{\mathrm{Qn} / \mathrm{Qn}}$ mice at $3 \mathrm{~h}$ WRS was significantly higher than that in GR ${ }^{\mathrm{wt} / \mathrm{wt}}$ mice $(\mathrm{p}<0.05)$. The serum TNF concentration was comparable to the IL-10 level. A small increase was observed in $\mathrm{GR}^{\mathrm{wt}}$ mice at $6 \mathrm{~h}$ of WRS (data not shown). Other cytokines examined showed no obvious quantitative difference in response to WRS under these experimental conditions. 
A

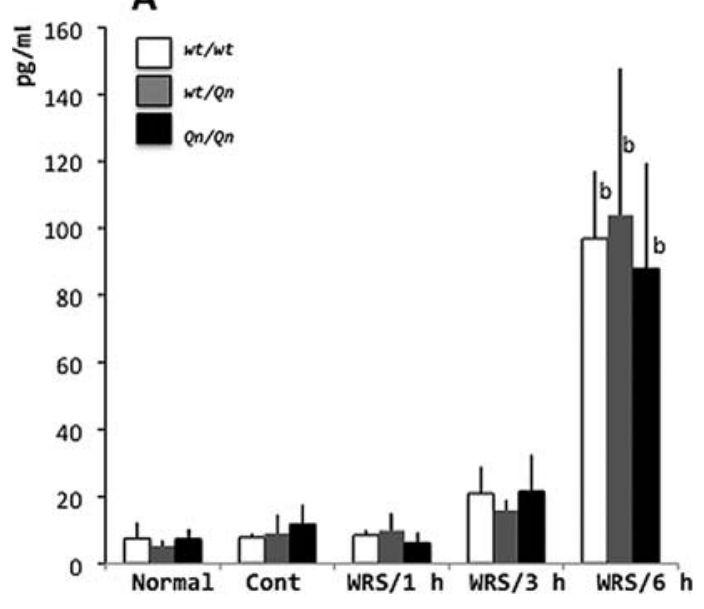

B

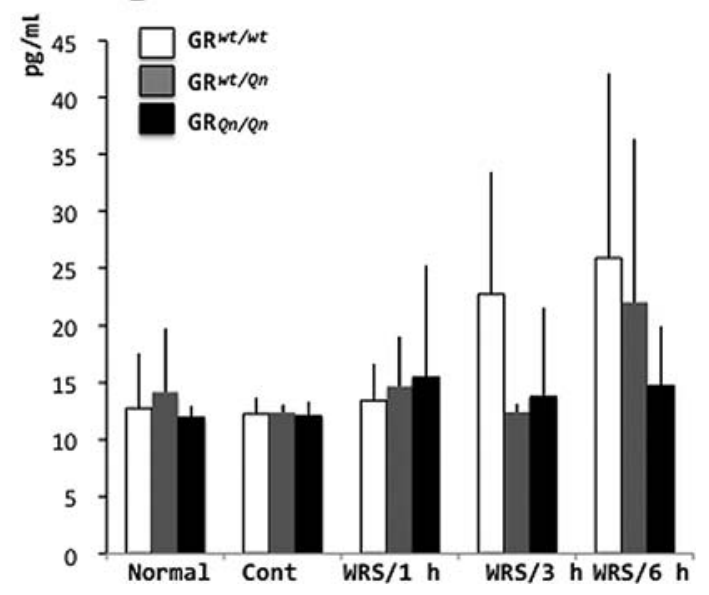

Figure 4. Time course of serum cytokine concentration in the GR polymorphic lines of ICR mice after exposure to WRS. A, IL-6; B, IL-10. ${ }^{b} \mathrm{p}<0.01$ vs. normal.

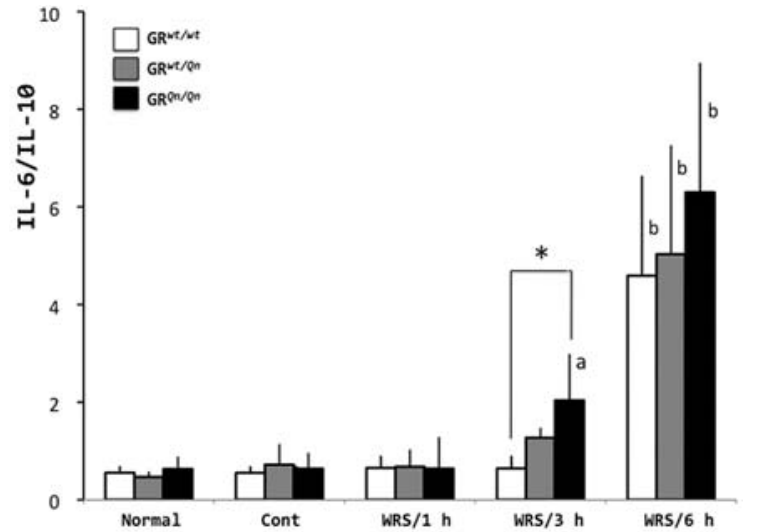

Figure 5. Time course of IL-6/IL-10 ratio in the GR polymorphic lines of ICR mice after exposure to WRS. ${ }^{\mathrm{a}} \mathrm{p}<0.05$ vs. normal; ${ }^{\mathrm{b}} \mathrm{p}<0.01$ vs. normal, ${ }^{*} \mathrm{p}<0.05$.

Differences in serum HSP70 levels. Hsp70 is induced when a cell undergoes various types of stress. Although serum Hsp70 concentrations did not reach a detectable level in normal and control groups, it was detectable at $6 \mathrm{~h}$ of WRS and was found to be significantly increased in mice with $\mathrm{GR}^{\mathrm{Q}}$ allele $(\mathrm{p}<0.05$, $\mathrm{GR}^{\mathrm{wt} / \mathrm{wt}}$ vs. GR $\mathrm{Qn}^{\mathrm{Qn} / \mathrm{Qn}}$ ) (Table I).

\section{Discussion}

The present study shows that the GR polymorphism, which exists in the N-terminus of the GR gene, affects the biological activities of mice exposed to WRS. Heeley et al previously reported that rats with natural GR polymorphic lines have similar ligand binding affinity to dexamethasone and corticosterone (20). However, artificial alteration of the length of CAG repeats, results in the mutant form of GR exhibiting significantly higher steroid binding affinity (21). These results suggest a possible domain-domain interaction between the poly Q and ligand binding regions within the GR gene. In the present experiment, different polymorphic lines of GR were selected from a commonly used mouse strain using a previously described method (9), and the influence of the natural GR polymorphism on the response to WRS was examined. As
Table I. Comparison of serum Hsp70 levels among the GR polymorphic lines at normal, control (overnight fasting), and $6 \mathrm{~h}$ of WRS conditions.

\begin{tabular}{lccc}
\hline & GR $^{\mathrm{w} t / \mathrm{wt}}$ & $\mathrm{GR}^{\mathrm{w} / \mathrm{Qn}}$ & $\mathrm{GR}^{\mathrm{Qn} / \mathrm{Qn}}$ \\
\hline Normal & n.d. & n.d. & n.d. \\
Control & n.d. & n.d. & n.d. \\
WRS $/ 6$ h & $0.42 \pm 0.34$ & $1.50 \pm 0.94$ & $1.80 \pm 0.96^{*}$ \\
\hline${ }^{*} \mathrm{p}<0.05$ vs. GR & & \\
\hline
\end{tabular}

expected, time-dependent, severe gastric lesions developed on the gastric mucosal membrane and severe bleeding was observed. In addition, both the changes in housing conditions and overnight fasting resulted in minor petechial bleeding, indicating that the treatment alone also effectively induces stress to animals. The lesion index was significantly greater in male $\mathrm{GR}^{\mathrm{Qn} / \mathrm{Qn}}$ mice than $\mathrm{GR}^{\mathrm{wt} / \mathrm{wt}}$ mice at $6 \mathrm{~h}$ exposure to WRS. This difference in the lesion index between the GR polymorphic lines was not observed in female mice. In a study assessing gender differences, estrogen was found to play an important role in the reduction of stress-induced gastric mucosal injury in mice through the production of calcitonin gene-related peptide (CGRP) in sensory neurons and, therefore, may account for gender differences found in WRS-induced ulceration (22).

The results from the present experiments represent an interesting pattern and indicate a difference in stress-induced corticosterone output between GR polymorphic lines. As shown in Fig. 3, the corticosterone level peaked at $3 \mathrm{~h}$ of WRS, followed by downregulation. The rank order of the serum levels in the control group during early stress was $\mathrm{GR}^{\mathrm{wt} / \mathrm{wt}}>\mathrm{GR}^{\mathrm{wt} / \mathrm{Qn}^{\mathrm{n}}}>\mathrm{GR}^{\mathrm{Qn} / \mathrm{Qn}}$, indicating that the levels in the former 2 lines were significantly increased $(\mathrm{p}<0.05)$. On the contrary, the order of the levels at $6 \mathrm{~h}$ of WRS was reversed as compared to the controls, $\mathrm{GR}^{\mathrm{Qn} / \mathrm{Qn}}>\mathrm{GR}^{\mathrm{wt} / \mathrm{Qn}}>\mathrm{GR}^{\mathrm{wt} / \mathrm{wt}}$. $\mathrm{GR}^{\mathrm{Qn} / \mathrm{Qn}}$ mice exhibited a significantly high corticosterone level as compared to $\mathrm{GR}^{\mathrm{wt} / \mathrm{wt}}$ mice $(\mathrm{p}<0.05)$, suggesting that the 
response to stress by the $\mathrm{GR}^{\mathrm{wt}}$ allele occurs very rapidly. However, the present results are in contrast to those obtained by $\mathrm{Xu}$ et al (9) who showed that both $\mathrm{GR}^{\mathrm{Qn} / \mathrm{Qn}}$ and $\mathrm{GR}^{\mathrm{w} t / \mathrm{Qn}}$ mice had a much weaker corticosterone response to stress and more increased anxiety-type behaviors than $\mathrm{GR}^{\mathrm{wt} / \mathrm{wt}}$ mice. The reasons for this discrepancy between studies may depend on the method of stress and/or exposure duration to stress. $\mathrm{Xu}$ et al applied a 30-min restraint stress to mice, followed by collection of serum at 30 and $50 \mathrm{~min}$ after the start of restraint (9). Other investigators used GR-heterozygous mutant mice $\left(\mathrm{GR}^{+/-}\right)$with a $50 \%$ GR gene dose reduction (23). Results from these studies indicate that the increase in corticosterone levels by immobilization was higher in $\mathrm{GR}^{+-}$mice at 40 and $60 \mathrm{~min}$ after stress, and the mutant mice showed increased anxiety-type behavior. Based on these findings, the elevations in corticosterone levels may not always yield the same physiological effects.

The IL-6 levels of each polymorphic line increased at $3 \mathrm{~h}$ and particularly at $6 \mathrm{~h}$ ( $\mathrm{p}<0.01 \mathrm{vs}$. other groups) of WRS. Previous studies in animals have provided evidence of the involvement of the hepatic sympathetic nerve system in the upregulation of serum IL-6 during various kinds of stress $(15,16)$. Kitamura et al (24) showed that immobilization stress induced IL-6 mRNA expression in the liver in parallel with elevations in the plasma IL-6 level. A large body of evidence indicates that endogenous norepinephrine, which is released from the end terminal of the hepatic sympathetic nerve, is responsible for stress-induced IL-6 production in the liver, thereby increasing the IL-6 levels in blood. Furthermore, IL-10 is a prototypical anti-inflammatory cytokine originally identified as a Th2-secreted counter-regulatory factor. IL-10 inhibits the synthesis and release of proinflammatory cytokines such as IL-6 and TNF, and also suppresses cellular immunity $(25,26)$. In the present study, a difference in the stress-induced IL-10 response among the GR polymorphic lines was observed. IL-10 levels in GR ${ }^{\mathrm{wt} / \mathrm{wt}}$ and $\mathrm{GR}^{\mathrm{wt} / \mathrm{Qn}}$ mice tended to increase in response to exposure to WRS, whereas the levels in $\mathrm{GR}^{\mathrm{Qn} / \mathrm{Qn}}$ mice remained unaffected. Thus, the ratio of IL-6/IL-10 was increased in the order of $\mathrm{GR}^{\mathrm{Qn} / \mathrm{Qn}}>\mathrm{GR}^{\mathrm{wt} / \mathrm{Qn}}>\mathrm{GR}^{\mathrm{wt} / \mathrm{wt}}$, suggesting that GR polymorphism affects cytokine output in response to stress. These results suggest that the gastric hemorrhage in $\mathrm{GR}^{\mathrm{Qn} / \mathrm{Qn}}$ mice was more pronounced than in $\mathrm{GR}^{\mathrm{wt} / \mathrm{wt}}$ mice at $6 \mathrm{~h}$ of WRS.

Hsps are induced when a cell is exposed to various types of environmental stress. Their main function is to promote cellular tolerance against stress factors in order to maintain normal cellular physiological functions. The translocation of Hsp70 from cytoplasm to nucleus may play a critical role in enhancing cell survival. Overexpression of Hsp70 has been observed in rats with gastric ulcers and chronic atrophic gastritis, and in patients with gastric cancer (27-29). Shichijo et al (17) reported that the Hsp70 overexpression in the stomach of SHR was highly correlated with ulcer resistance. Increased Hsp70 expression might be related to the synthesis and activity of growth factors, cytokines, and COX-2 (30). In the present study, the EIA data for serum Hsp70 levels suggest that there is a clear difference in the WRS-induced effect among the GR polymorphic lines. The Hsp70 level in the serum of mice with $\mathrm{GR}^{\mathrm{Qn}}$ allele was particularly increased at $6 \mathrm{~h}$ of WRS, and the serum concentration in $\mathrm{GR}^{\mathrm{Q}}{ }^{\mathrm{n}} \mathrm{Qn}^{\mathrm{n}}$ mice was significantly increased as compared to $\mathrm{GR}^{\mathrm{wt} / \mathrm{wt}}$ mice $(\mathrm{p}<0.05)$. These results suggest that GR polymorphism affects Hsp response to stress. Although further studies are needed to clarify the area where Hsp70 is expressed in abundance, the injury may become more severe in cases where substantial leakage of proteins into blood has occurred.

In conclusion, we conducted a genetic screening for the polymorphic lines of GR, GR ${ }^{\mathrm{wt} / \mathrm{wt}}, \mathrm{GR}^{\mathrm{wt} / \mathrm{Qn}}$, and $\mathrm{GR}^{\mathrm{Qn} / \mathrm{Qn}}$, in the commonly used mouse strain and investigated the involvement of the GR polymorphism in stress response by using WRS. Our results suggested that the GR gene polymorphism significantly affected the stress-induced output, including gastric lesion index, and the serum corticosterone, serum cytokines, and serum Hsp70 levels. The present study may provide insights into the role of GR in individual stress responses.

\section{Acknowledgements}

This study was supported, in part, by a Grant-in-Aid for Scientific Research (No. 19590684) and by Research Project Grants (Nos. 20-4090 and 21-415) from Kawasaki Medical School.

\section{References}

1. Meaney MJ, Diorio J, Francis D, et al: Early environmental regulation of forebrain glucocorticoid receptor gene expression: implications for adrenocortical responses to stress. Dev Neurosci 18: 49-72, 1996.

2. Linthorst AC, Flachskamm C, Barden N, Holsboer F and Reul JM: Glucocorticoid receptor impairment alters CNS responses to a psychological stressor: an in vivo microdialysis study in transgenic mice. Eur J Neurosci 12: 283-291, 2000.

3. Kumsta R, Moser D, Streit F, Koper JW, Meyer J and Wüst S: Characterization of a glucocorticoid receptor gene (GR, NR3C1) promoter polymorphism reveals functionality and extends a haplotype with putative clinical relevance. Am J Med Genet B Neuropsychiatr Genet 150 (suppl B): 476-482, 2009.

4. Van Rossum EF and Lamberts SW: Polymorphisms in the glucocorticoid receptor gene and their associations with metabolic parameters and body composition. Recent Prog Horm Res 59: 333-357, 2004.

5. Derijk RH and de Kloet ER: Corticosteroid receptor polymorphisms: determinants of vulnerability and resilience. Eur J Pharmacol 583: 303-311, 2008.

6. Brouwer JP, Appelhof BC, van Rossum EF, et al: Prediction of treatment response by HPA-axis and glucocorticoid receptor polymorphisms in major depression. Psychoneuroendocrinology 31: 1154-1163, 2006

7. Wüst S, Van Rossum EF, Federenko IS, Koper JW, Kumsta R and Hellhammer DH: Common polymorphisms in the glucocorticoid receptor gene are associated with adrenocortical responses to psychosocial stress. J Clin Endocrinol Metab 89: 565-573, 2004.

8. Ogasawara M, Imanishi $\mathrm{T}$, Moriwaki $\mathrm{K}$, et al: Length variation of CAG/CAA triplet repeats in 50 genes among 16 inbred mouse strains. Gene 349: 107-119, 2005.

9. $\mathrm{Xu} \mathrm{D}$, Buehner A, Xu J, et al: A polymorphic glucocorticoid receptor in a mouse population may explain inherited altered stress response and increased anxiety-type behaviors. FASEB J 20: E1802-E1810, 2006.

10. Yee KS, Cho K, Green T, Chandler J and Greenhalgh DG: The effect of $\mathrm{CAG}$ repeat length polymorphism in the murine glucocorticoid receptor on transactivation potential. Exp Mol Pathol 84: 200-205, 2008.

11. Takagi $\mathrm{K}$ and Okabe $\mathrm{S}$ : The effects of drugs on the production and recovery processes of the stress ulcer. Jpn J Pharmacol 18: 9-18, 1968.

12. Lou LX, Geng B, Yu F, et al: Endoplasmic reticulum stress response is involved in the pathogenesis of stress induced gastric lesions in rats. Life Sci 79: 1856-1864, 2006. 
13. Zhou D, Kusnecov AW, Shurin MR, DePaoli M and Rabin BS: Exposure to physical and psychological stressors elevates plasma interleukin 6: relationship to the activation of hypothalamicpituitary-adrenal axis. Endocrinology 133: 2523-2530, 1993.

14. Takaki A, Huang QH, Somogyvári-Vigh A and Arimura A: Immobilization stress may increase plasma interleukin-6 via central and peripheral catecholamines. Neuroimmunomodulation 1: 335-342, 1994.

15. Nukina H, Sudo N, Aiba Y, Oyama N, Koga Y and Kubo C: Restraint stress elevates the plasma interleukin-6 levels in germfree mice. J Neuroimmunol 115: 46-52, 2001.

16. Chida Y, Sudo N, Motomura Y and Kubo C: Electric foot-shock stress drives TNF-alpha production in the liver of IL-6-deficient mice. Neuroimmunomodulation 11: 419-424, 2004.

17. Shichijo K, Ihara M, Matsuu M, Ito M, Okumura Y and Sekine I: Overexpression of heat shock protein 70 in stomach of stressinduced gastric ulcer-resistant rats. Dig Dis Sci 48: 340-348, 2003.

18. Guo JS, Chau JF, Shen XZ, Cho CH, Luk JM and Koo MW: Over-expression of inducible heat shock protein 70 in the gastric mucosa of partially sleep-deprived rats. Scand J Gastroenterol 39: 510-515, 2004

19. Nie SN, Qian XM, Wu XH, et al: Role of TFF in healing of stressinduced gastric lesions. World J Gastroenterol 9: 1772-1776, 2003.

20. Heeley RP, Gill E, van Zutphen B, Kenyon CJ and Sutcliffe RG: Polymorphisms of the glucocorticoid receptor gene in laboratory and wild rats: steroid binding properties of trinucleotide CAG repeat length variants. Mamm Genome 9: 198-203, 1998.

21. Heeley RP, Rusconi SG, Sutcliffe RG and Kenyon CJ: Mutations flanking the polyglutamine repeat in the modulatory domain of rat glucocorticoid receptor lead to an increase in affinity for hormone. Endocr Res 28: 217-229, 2002.
22. Shimozawa N, Okajima K, Harada N, et al: Contribution of sensory neurons to sex difference in the development of stressinduced gastric mucosal injury in mice. Gastroenterology 131: 1826-1834, 2006.

23. Ridder S, Chourbaji S, Hellweg R, et al: Mice with genetically altered glucocorticoid receptor expression show altered sensitivity for stress-induced depressive reactions. J Neurosci 25: 6243-6250, 2005.

24. Kitamura H, Konno A, Morimatsu M, Jung BD, Kimura K and Saito M: Immobilization stress increases hepatic IL-6 expression in mice. Biochem Biophys Res Commun 238: 707$711,1997$.

25. Howard M and O'Garra A: Biological properties of interleukin 10. Immunol Today 13: 198-200, 1992.

26. Moore KW, de Waal Malefyt R, Coffman RL and O'Garra A: Interleukin-10 and the interleukin-10 receptor. Ann Rev Immunol 19: 683-765, 2001.

27. Maehara Y, Oki E, Abe T, et al: Overexpression of the heat shock protein HSP70 family and p53 protein and prognosis for patients with gastric cancer. Oncology 58: 144-151, 2000.

28. Chang XR, Peng L, Yi SX, Peng Y and Yan J: Association of high expression in rat gastric mucosal heat shock protein 70 induced by moxibustion pretreatment with protection against stress injury. World J Gastroenterol 13: 4355-4359, 2007.

29. Liu WL, Chen SJ, Chen Y, et al: Protective effects of heat shock protein70 induced by geranylgeranylacetone in atrophic gastritis in rats. Acta Pharmacol Sin 28: 1001-1006, 2007.

30. Tsukimi Y and Okabe S: Recent advances in gastrointestinal pathophysiology: role of heat shock proteins in mucosal defense and ulcer healing. Biol Pharm Bull 24: 1-9, 2001. 